\title{
A ANPEd, a pós-graduação, a pesquisa e a veiculação da produção intelectual na área da educação
}

\author{
Alceu Ravanello Ferraro
}

Escola Superior de Teologia, São Leopoldo (RS)

\section{Introdução}

Como o próprio nome o diz, a Associação Nacional de Pós-Graduação e Pesquisa em Educação (ANPEd) mantém vínculos com dois campos de interesse bem distintos, embora estreitamente relacionados entre si: a pós-graduação em educação e a produção e disseminação do conhecimento nessa mesma área. O tema que me foi proposto - “A ANPEd, a pós-graduação, a pesquisa e a veiculação da produção intelectual na área da educação”, acrescido da especificação "resgate de cunho empírico, evolução, produção etc." - abarca, especifica e, ao mesmo tempo, alarga o conteúdo já sugerido pelo nome da associação.

Excederia em muito a dimensão de um artigo e avançaria nos temas de outros e outras colegas a pretensão de dar conta dessas duas áreas de interesse da ANPEd em seus vinte e sete anos de existência e dos múltiplos aspectos compreendidos no tema proposto. Fica, assim, excluída qualquer pretensão de escrever a história dessa dupla relação da ANPEd: com a pós-graduação e com a produção e disseminação do conhecimento. Obrigo-me, por isso, a optar por alguns aspectos capazes de projetar luz sobre o tema proposto.
Há ainda um ponto que precisa ser explicitado desde o início. Não tenho dúvida de que essa tarefa me foi proposta não enquanto estudioso da ANPEd, mas como ator. Não como ator individual, solitário, mas na condição de membro de um coletivo muito especial, constituído por convicções e laços afetivos muito fortes entre todos os que repartimos a responsabilidade das gestões 1989-1991 e 1991-1993 da ANPEd. Na realidade, esse coletivo - como espero ficará claro na argumentação que segue - estendeuse sempre para muito além da diretoria da associação. Escrevo na primeira pessoa porque o esforço de reavivar a memória é também um ato de seleção e de interpretação, e não quereria responsabilizar esse coletivo por omissões ou distorções em que possa estar incorrendo neste meu rememorar. Agradeço desde já pelas contribuições e críticas que me puderem ser oferecidas.

O ângulo de onde ou a perspectiva pela qual examino a questão proposta é o período em que estive diretamente envolvido, como membro de uma equipe, na administração da ANPEd, em dois biênios sucessivos, nos anos 1989-1991 e 1991-1993. Se, no momento em que escrevo este texto, dividisse a trajetória 
da ANPEd em duas partes iguais de tempo, esses dois biênios marcariam o final da primeira e o início da segunda metade. É claro que tomar esse período como ângulo ou perspectiva pode significar o privilegiamento de concepções, fatos, problemas, projetos e atividades que marcaram esse período. Mas, uma vez declarada a opção e reconhecidas as limitações que daí podem advir, fica aberto o caminho para contestações e complementações da parte de tantos outros atores que fizeram e continuam fazendo a ANPEd.

O que apresento não é, pois, uma pesquisa sobre a trajetória da ANPEd. É, antes, o olhar comprometido de um ator, a quem, em determinado momento, em parceria com toda uma equipe de colegas que sempre trabalhou junto, foi confiado, por dois biênios consecutivos, o desafio de pôr em execução uma proposta claramente explicitada quando do lançamento da chapa na $12^{\mathrm{a}}$ Reunião Anual, ${ }^{1}$ realizada na Universidade de São Paulo (USP) de 8 a 12 de maio de 1989, e novamente na $14^{\mathrm{a}}$ Reunião Anual, ${ }^{2}$ também na USP, de $1^{\circ}$ a 3 de setembro de 1991.

${ }^{1}$ A chapa estava assim composta: presidente: Alceu Ravanello Ferrari (Universidade Federal do Rio Grande do Sul - UFRGS); vicepresidentes: Ozir Tesser (Universidade Federal do Ceará - UFC), Miguel Gonzales Arroyo (Universidade Federal de Minas Gerais UFMG), Marília Pontes Sposito (Universidade de São Paulo - USP); secretário geral: Nilton Bueno Fischer (UFRGS); secretário adjunto: Tomaz Tadeu da Silva (UFRGS); conselho fiscal - titulares: José Luiz Domingues (Universidade Federal de Goiás - UFGO), Marília Martins da Costa Cruz (Instituto de Estudos Avançados em Educação, Fundação Getúlio Vargas - IESAE-FGV) e Marileide de C. Costa (Universidade Federal de Pernambuco - UFPE); Suplentes: Bruno Pucci (Universidade Federal de São Carlos - UFSCar), José Erno Taglieber (Universidade Federal de Santa Catarina - UFSC) e José Carlos Abrão (Universidade Federal do Mato Grosso do Sul UFMS) (Boletim ANPEd, 1989, p. 87-88).

${ }^{2}$ Inscreveu-se a mesma chapa de 1989, com uma única alteração: secretário adjunto: Sérgio Haddad (Centro Ecumênico de Documentação e Informação - CEDI) (Boletim ANPEd, 1991, p. 75). Desejo registrar que a participação do colega Sérgio Haddad representou um reforço inestimável para o trabalho desenvolvido na gestão 1991-1993.
Para completar a apresentação, diria que o caminho que em 1989 me levou à presidência da ANPEd correra mais por fora do que por dentro da associação. Embora tivesse participado de várias reuniões anuais, inclusive da primeira, em Fortaleza, em 1978, certamente eu não fazia parte das lideranças mais destacadas da ANPEd. Acredito que a busca do meu nome, em 1989, para integrar uma chapa já praticamente constituída, deveu-se principalmente à relativa evidência a que fora exposto no processo de eleição para reitor da UFRGS: primeiro, na condição de candidato mais votado; a seguir, pela repercussão que teve a nomeação, pelo então presidente da República, do terceiro da lista, apesar do compromisso público entre os candidatos, inclusive o nomeado, de somente o mais votado aceitar o cargo.

Dito isso, vou organizar o texto em torno de alguns pontos selecionados para o desenvolvimento do tema, começando com o que considero ser uma questão de fundo na relação entre pesquisa e pós-graduação, ou melhor, entre pesquisa e ensino universitário.

\section{A relação entre pós-graduação e pesquisa: uma anomalia congênita}

A própria ordem dos termos pós-graduação e pesquisa no nome da associação não deve ser gratuita. Entendo que ela espelha a condição anômala do surgimento, se não de toda, pelo menos da maior parte da pós-graduação no Brasil. Com efeito, em vez de ter emergido de uma prática consolidada de pesquisa, a pós-graduação foi criada com o propósito explícito de promover a pesquisa na ainda principiante universidade brasileira. Dessa forma, a pesquisa, em vez de função básica da universidade e condição preliminar do próprio ensino universitário enquanto tal - de graduação e, com maior razão, de pós-graduação -, passou a ser vista e tratada como função da pós-graduação, e esta, por sua vez, como o locus da produção do conhecimento.

Deve ter influído nesse tipo de encaminhamento da pós-graduação o caráter de urgência que lhe deu o regime militar, em função do ambicioso projeto de 
desenvolvimento nacional, com vista a elevar o país à condição de potência mundial. Ricardo C. de Rezende Martins observa que a aceleração do desenvolvimento do sistema nacional de programas de mestrado e doutorado no país teve seu ponto de partida em fins da década dos anos de 1960 e que tal aceleração se teria dado dentro do quadro de "uma nova ordem política que, por ações rápidas e efetivas, pretendia apresentar resultados que justificassem sua implantação, particularmente no domínio econômico" (Martins, 1991, p. 94).

Segundo o mesmo autor, essa política de formação de recursos humanos obedecia a duas linhas fundamentais: de um lado, "a necessidade futura de mãode-obra especializada para preencher os novos empregos criados pelo desenvolvimento econômico previsto"; de outro, "a necessidade de cientistas, pesquisadores e técnicos aptos a desenvolver a pesquisa indispensável para a mudança, ao longo dos anos, do eixo de origem e de sustentação do desenvolvimento, do exterior em direção ao próprio País” (idem, ibidem).

A pós-graduação precedeu, pois, a pesquisa no Brasil. O que a partir dos últimos anos da década de 1960 era verdade para a universidade brasileira em geral, era-o com maior força para todos os campos do conhecimento hoje reunidos sob os nomes de ciências humanas e ciências sociais aplicadas, que haviam sempre disputado com desvantagem, em relação às demais áreas do conhecimento, os escassos recursos destinados pelos poderes públicos à pesquisa no país. ${ }^{3}$

${ }^{3}$ Duas avaliações de meados dos anos de 1980, acerca de quinze anos do início da pós-graduação na área, esclarecem isto: “As peculiaridades do desenvolvimento político-econômico do país na última década beneficiaram, durante todos estes anos, as áreas exatas e mais técnicas do conhecimento. Basta lembrar que, em 1980, do orçamento do [Conselho Nacional de Desenvolvimento Científico e Tecnológico] CNPq apenas 4,36\% - a menor taxa - estava alocada para a área de Ciências Humanas e Sociais, que engloba treze subáreas, entre elas a Educação. É mínima, portanto, a participação da Educação no orçamento do CNPq"
No campo da educação especificamente, o pouco de pesquisa que se podia identificar às vésperas da indução da pós-graduação na área vinha em grande parte de fora da universidade. ${ }^{4}$ Isso era particularmente verdadeiro para as recém-criadas faculdades de educação, estimuladas, em sua grande maioria, a ingressar na pós-graduação sem qualquer prática anterior mais sistemática de pesquisa.

Diante desse quadro, penso que não seria inoportuno lembrar, mesmo que muito brevemente, as condições que, do ponto de vista da pesquisa, antecederam a indução da pós-graduação na área de educação.

\section{Gênese e primeiros passos da pesquisa em educação}

Recorro novamente ao já referido estudo de Aparecida Joly Gouveia. A autora distingue, em seu trabalho, três períodos na curta trajetória da pesquisa em educação no Brasil até o ano de 1970. Ela destaca, como marco inicial do primeiro período, a fundação do Instituto Nacional de Estudos Pedagógicos (INEP), no ano de 1938, pelo Ministério da Educação e Cultura (MEC), com a incumbência de realizar pes-

(Gatti, 1983, p. 16); “Fazer pesquisa em Educação no Brasil não é uma tarefa simples, por uma série de razões que a maioria de nós bem conhece. Estamos lidando com uma área que não tem se configurado como prioritária no quadro das políticas governamentais brasileiras” (Vieira, 1985, p. 82).

${ }^{4}$ Em relação a isso, Aparecida Joly Gouveia, em estudo sobre a pesquisa educacional no Brasil, publicado no número de lançamento dos Cadernos de Pesquisa, da Fundação Carlos Chagas, em julho de 1971, classificou os 206 projetos de pesquisa iniciados ou concluídos nos cinco anos que antecederam o seu estudo. Se os dados apresentados por Gouveia forem tabulados de acordo com o critério "base institucional do pesquisador principal”, chega-se ao seguinte resultado: 58,2\% dos projetos estudados provinham de organizações ou centros não-universitários de pesquisa; os outros 41,2\% mantinham algum tipo de vínculo com universidades; apenas 11,2\% provinham de centros de pesquisa inseridos em universidades (Gouveia, 1971, p. 21-48). 
quisa sobre os problemas de ensino no Brasil. Predominaram, nesse primeiro período, estudos de natureza psicopedagógica (Gouveia, 1971, p. 2).

O segundo período, que se estendeu de 1956 a 1964, teve como referência inicial a criação, pelo próprio INEP, no ano de 1956, do Centro Brasileiro de Pesquisa Educacional e dos Centros Regionais de Pesquisa, localizados nas capitais dos estados do Rio Grande do Sul, São Paulo, Minas Gerais, Bahia e Pernambuco, incumbidos de desenvolver pesquisas com vistas à elaboração de uma política educacional para o país. Predominaram, aqui, estudos de natureza sociológica (idem, p. 3).

O terceiro período, já nos primeiros anos da Ditadura Militar e véspera da “campanha” da pós-graduação, estendeu-se de 1964 até o momento da conclusão do estudo em questão (1970 ou início de 1971), com predominância, agora, de estudos de natureza econômica (idem, p. 4).

Em relação ao primeiro período (1938-1963) distinguido por Gouveia, Luiz Antônio Cunha antecipalhe o início para antes de 1938 (data da criação do INEP); mais precisamente para o serviço de teses instituído por Anísio Teixeira, em 1932, no Departamento de Educação da prefeitura do então Distrito Federal (Cunha, 1979, p. 3, nota 2). Pedro Goergen (1986, p. 5), em interessante trabalho sobre a pesquisa educacional no Brasil, lembra essa observação de Cunha, mas sem avaliar-lhe o mérito. Penso que a conferência de Lourenço Filho “Estatística e educação”, justamente no ano de criação do INEP, 1938, proferida no curso de informações organizado pelo recém-criado Instituto Brasileiro de Geografia e Estatística (IBGE), ${ }^{5}$ confirma e alarga a pista aberta por Cunha, acrescentando-lhe elementos que poderiam ser aprofundados. Primeiramente, Lourenço Filho lembra algumas iniciativas que tiveram repercussão, se não na pesquisa em si, pelo menos na disponibilização de dados estatísticos para a pesquisa. São eles: o levantamento ou censo da população escolar no estado de São Paulo,

\footnotetext{
${ }^{5}$ O IBGE foi criado em 29 de maio de 1936.
}

em 1920, sendo diretor da Instrução Pública Sampaio Dória; o recenseamento ou cadastro escolar no estado do Ceará, em 1922, de cujas análises teria resultado "uma nova política de educação" naquele estado; finalmente, o recenseamento escolar promovido na capital federal, em 1927, pelo então diretor da Instrução Pública Fernando de Azevedo, do qual "serviu-se o dr. Anísio Teixeira, quando diretor do Departamento de Educação, para providências de grande melhoria nos serviços de ensino" (Lourenço Filho, 1940, p. 75-77).

Na seqüência, Lourenço Filho cita relatório de Anísio Teixeira, publicado em 1935, em que este se refere aos "laboriosos estudos estatísticos" por ele desenvolvidos, que lhe permitiram chegar à "conclusão que [tais estatísticas] só podem ser postas em dúvida como inferiores à realidade, em relação à população escolar do Rio de Janeiro, sua distribuição e seu crescimento" (idem, p. 77-78). Estendendo-se na análise do referido plano de Anísio Teixeira, que se fundamentava nos resultados do censo escolar realizado por Fernando de Azevedo, Lourenço Filho conclui: "Esse trabalho demonstra que o nosso aparelhamento de educação primária, sobre ser deficiente, para as necessidades da população escolar, o que não surpreende a ninguém, é também muito mais ineficiente, quanto à sua produção, do que vulgarmente se imagina” (idem, p. 78, grifos do original).

Há outra passagem interessante no texto em exame. Referindo-se aos trabalhos apresentados à Academia Brasileira de Letras por Frota Pessoa, Júlio Nogueira, Deodato e Buchler e Osvaldo Orico, sobre o melhor modo de divulgar o ensino primário no país (Prêmio Francisco Alves), Lourenço Filho deixa entrever já aí alguma preocupação de pesquisa: “Todos [esses trabalhos] não desdenham o valor das cifras. Mas se debatem no esforço de encontrá-las, pois foram compostos antes de 1932, ou seja, antes do Convênio Interestadual de Estatísticas Escolares” (idem, p. 79).

E, para completar, acentuaria que a própria criação do IBGE deve ser encarada como mais um fator de fundamental importância no que se poderia definir 
como a criação das condições básicas para a emergência, mesmo que tímida ainda, da pesquisa em educação no Brasil.

Essa preocupação com a identificação dos primeiros passos serve para evidenciar o estado de miserabilidade da pesquisa em educação no Brasil até a época em questão.

\section{Da paternidade ou maternidade da ANPEd}

Depois da digressão a que fui levado no item anterior, volto à ANPEd. Mais precisamente, à questão da paternidade ou maternidade da associação e à análise das condições de seu surgimento. Excetuados os dois programas de mestrado em educação da Pontifícia Universidade Católica do Rio de Janeiro (PUCRio) e da Pontifícia Universidade Católica de São Paulo (PUC-SP), que datam da segunda metade da década de 1960, a pós-graduação em educação teve início no começo dos anos de 1970. Em 1978, ano da criação da ANPEd, a área da educação já contava com 29 programas de pós-graduação, dos quais 25 de mestrado e quatro de doutorado (Brandão, 1986, p. 2627). Essa explosão, verificada quase toda no curto período de 1972 a 1978, levou a autora à seguinte hipótese de trabalho, que valeu como um alerta:

Parto da hipótese de que a expansão do ensino superior entre nós vem pressionando fortemente a demanda por cursos de pós-graduação; e que estes, hoje, correm o risco de sofrer um processo de expansão, tão indesejável para a preservação do caráter substantivo da pós-graduação quanto se mostrou a expansão do ensino superior para a graduação. (idem, p. 25)

Foi, pois, no ano de 1978 que, como fruto de longa gestação e obra, até certo ponto, de parto induzido, finalmente foi dada à luz a ANPEd. Em relação a esse fato primeiro, há uma questão preliminar a esclarecer: a da paternidade/maternidade da associação. Esse aspecto é importante para se analisar outras duas questões: a da relação entre a ANPEd e as agências governamentais de ensino e de pesquisa, e a da natu- reza e do rumo tomado pela associação em sua trajetória através dos pouco mais de 25 anos de vida.

Não testemunhei pessoalmente esse momento. Valho-me, por isso, de depoimentos de colegas que testemunharam.

O primeiro depoimento é de quem a diretoria do biênio 1993-1995 qualificou de "uma das 'memórias vivas' da ANPEd” (ANPEd, 1995, p. 5). Trata-se de ninguém menos do que a professora Maria Julieta Costa Calazans, uma das articuladoras na fase de concepção e nascimento e, a seguir, secretária geral por dois mandatos, e, por um mandato, presidente da entidade. "É bom recordar - diz ela a propósito da origem da ANPEd - que as associações nacionais de pós-graduação (de todas as áreas) não são instrumentos das políticas do Estado, mas nasceram sob o patrocínio destas.” (Calazans, 1995, p. 9, grifo do original). E prossegue afirmando que é complexa a tarefa de falar das origens das associações científicas no Brasil, particularmente da ANPEd, "em vista das diferentes interpretações que têm sido dadas ao papel do Estado e às iniciativas da sociedade civil na criação de tais entidades”. A eleição da primeira diretoria foi disputada no voto, com decisão apertada. É inegável o "patrocínio" estatal (idem, p. 10). Mas os fundadores e as fundadoras da associação optaram, em sua maioria, na eleição, por uma chapa que queria constituir uma associação identificada mais com a sociedade civil do que com o Estado.

O segundo depoimento, colho-o de Jacques Therrien, então em fase de conclusão de seu doutorado. A imagem que ele diz acompanhá-lo em toda sua trajetória profissional como docente e pesquisador é a seguinte:

A primeira janela que se abre para um olhar de memória viva sobre a ANPEd me situa, nos idos de 1978, num cenário de uma reunião em Curitiba, PR, patrocinada em boa parte pela CAPES, no intuito de fomentar a articulação dos profissionais e pesquisadores da área da educação. Estávamos nos tempos do $1^{\circ}$ Plano Nacional de Pós-Graduação (PNPG, 1975). Além dos representantes dos Programas de Pós-Graduação em Educação, a grande maioria 
de mestrados, estava presente o grupo articulador de criação da ANPEd, consolidando a proposta de seu estatuto inicial. Foi um importante momento de definição de propostas para a implementação de políticas nacionais de pesquisa e pós-graduação por parte daqueles que, vindos das mais diversas instituições de ensino superior do Brasil, particularmente públicas, estavam desenvolvendo pesquisas e programas de ensino. (Therrien, 2005) ${ }^{6}$

Essa opção inicial haveria de marcar toda a história da ANPEd. Surpreendem-me, por isso, duas interpretações referidas por Vera Maria Pereira de Miranda Henriques em sua tese de doutorado (1998, p. 140), que vinculam a eleição do primeiro presidente da associação, Jacques Velloso, seja à "posição estratégica da Universidade de Brasília”, seja ao “mérito pessoal da pessoa escolhida”. Nenhuma das duas razões está em discussão. Mas sempre entendi também que a alternativa vitoriosa não era a preferida da Coordenação de Aperfeiçoamento de Pessoal de Nível Superior (CAPES), e que foi isso que abriu espaço para uma certa autonomia e independência da entidade em relação àquela agência e, de um modo geral, também às diversas agências governamentais de pesquisa. Aliás, em outros momentos, os dois a(u)tores de primeira hora citados por Henriques (José Carmelo Carvalho e Osmar Fávero) defenderam outro ponto de vista. É Osmar Fávero que, em seu texto Política de pós-graduação em educação no Brasil (1993), enfatiza que, mesmo que a proposta da CAPES fosse a de criar uma associação representativa dos programas de pós-graduação em educação, à semelhança da Associação de Pós-Graduação em Economia (ANPEC), "a ANPEd desde sua criação adotou uma postura mais instituinte que instituída” (grifos do original). E esclarece e justifica citando, ao final, José Carmelo Carvalho:

${ }^{6}$ Trata-se de "Memória viva da ANPEd: um depoimento", contribuição, via e-mail, gentilmente oferecida por Jacques Therrien para o presente artigo.
Os esboços do primeiro estatuto da ANPEd já se afastavam em alguns pontos do da ANPEC, proposto como modelo, prevendo inclusive a admissão de sócios individuais. Mas na própria plenária da criação da ANPEd, realizada em 1978, na FGV/Rio, argüiu-se contra a função instituidora, interligada ao sistema de direção do I PNPG, e criticou-se a representatividade institucional através dos coordenadores de cursos. Em contrapartida aprovou-se “que a ANPEd exercesse uma função instituinte, como representante da sociedade civil, ecoando as necessidades e interesses dos grupos docentes, discentes e de pesquisadores. ${ }^{7}$

(Fávero, 1993, p. 36)

É esse caráter instituinte da ANPEd que permite compreender fatos da sua história, que serão lembrados no decorrer deste trabalho.

\section{Da natureza da ANPEd}

Pelo nome e pelo estatuto, foram determinados à ANPEd dois campos prioritários de interesse: a pósgraduação e a pesquisa. No entanto, seria ingenuidade imaginar que as coisas andam sempre e necessariamente de acordo com o nome e o estatuto. Penso que, para não cair nessa cilada, poderia tomar esses dois interesses prioritários como parâmetro para a avaliação da trajetória real da associação. A pergunta é simples, e consiste em saber em que medida esses dois interesses pautaram efetivamente a ação da ANPEd em seu pouco mais de um quarto de século de existência.

Vera Maria Henriques identifica na história da ANPEd uma tensão permanente entre questões de caráter científico e questões de caráter político. Com

${ }^{7}$ Fávero cita entrevista com José Carmelo Carvalho publicada no Boletim ANPEd, v. 8, n 3-4, p. 3-7, jul.-dez., 1986. Aliás, esse boletim contém contribuições preciosas, reunidas no sentido de "resgatar o passado para melhor entender o presente e o futuro", como se lê na nota editorial da secretária adjunta, Ira Maria Maciel (idem, p. 1). A referida entrevista foi republicada na Revista Brasileira de Educação, nº 17, maio-ago., 2001, p. 134-138. 
base na análise de oito textos produzidos no período de 1969 a 1990, a autora levanta uma hipótese sumamente provocadora. Nas suas palavras:

O espaço da pesquisa em educação parece ter estado sempre sob o crivo da busca de superação de uma oposição/ interação entre dois pólos que tentam, como adversários cúmplices, definir os limites do campo pela participação legítima na luta: questões científico-educacionais e questões políticas. (Henriques, 1998, p. 9)

Em relação à hipótese e, em termos mais gerais, à pesquisa desenvolvida por Henriques, faria apenas um reparo. Na minha interpretação, defrontamo-nos, aí, com duas concepções sobre a natureza da ANPEd e duas políticas distintas, que predominaram em diferentes momentos da caminhada da associação: uma, centrada na consolidação da pós-graduação e na produção e disseminação do conhecimento na área da educação ou no que a autora denomina "questões científico-educacionais"; a outra, voltada mais para o que a autora chama de "questões políticas”, o que, se bem entendi, significa o envolvimento na (re)formulação da política educacional no país por ocasião dos processos de redemocratização, de elaboração da Constituição de 1988 e, na seqüência, de elaboração da lei n ${ }^{\circ}$ 9.394/96 (Lei de Diretrizes e Bases da Educação Nacional - LDB).

São claras as conseqüências dessa discussão. De um lado, o estudo aqui desenvolvido não pode apoiarse no pressuposto de que a pós-graduação e a pesquisa tenham constituído de fato os dois únicos campos de interesse da associação. De outro, este estudo não pode excluir a priori a possibilidade de que algum outro tipo de interesse ou preocupação possa ter dominado a concepção e a prática da entidade em determinado(s) período(s). As coisas são o que são, não necessariamente o que as leis, os estatutos ou os nomes dizem que são.

Importa, pois, ter presente que, ao fato da quase ausência de pesquisa na área da educação quando da indução da pós-graduação a partir do início da década de 1970, deve-se acrescentar um outro elemento: a disputa que outros interesses mantiveram, em menor ou maior grau, em diferentes momentos, com os objetivos da pós-graduação e da pesquisa.

Por último, vale lembrar que, ao contrário de outras associações que congregam apenas programas de pós-graduação, a ANPEd optou por congregar não só programas de pós-graduação, mas também pesquisadores. O ex-presidente Jacques Velloso destacou esse fato, por entender que ele "imprimiu novo ritmo de trabalho em que você contava com pessoas trabalhando, e não com cursos apenas" (Velloso in Boletim ANPEd, 1986, p. 14, grifo meu). Estimo que essa foi uma das opções mais felizes e de maior alcance na história da associação. É isso que explica os dois fundamentos sobre os quais se apóiam a ANPEd e as suas práticas: de um lado, a base constituída pelos sócios individuais, pela estrutura de grupos de trabalho, pelas reuniões anuais e regionais, com a preocupação centrada na produção e disseminação do conhecimento, dando, por aí, sustentação à pós-graduação (ao ensino e às avaliações externas dos programas); de outro, a base constituída pelos programas de pós-graduação e o Fórum de Coordenadores, com a atenção voltada para a consolidação dos programas e para a participação como atores, não como meros pacientes, nas políticas públicas de pós-graduação e pesquisa, o que se traduz em apoio e benefício da produção e disseminação do conhecimento. É isso também que permite entender gestos de autonomia como o relatado pelo primeiro presidente da entidade, Jacques Velloso: “O marco mais importante na vida da ANPEd terá sido, talvez, o rompimento, a denúncia do convênio que se fez com a CAPES visando uma avaliação da pós-graduação” (idem, p. 13). Estimo que uma associação constituída somente de programas de pós-graduação dificilmente se exporia às conseqüências de um tal gesto.

\section{Nos primeiros dez anos da ANPEd}

Em artigo sobre a divulgação da pesquisa educacional no Brasil, de 1985, Pedro Goergen fazia uma avaliação pouco animadora da área em termos de meios 
de divulgação. Dizia ele então que "a falta de qualidade do trabalho e o descompromisso social do pesquisador”, se explicavam a não divulgação, só o faziam parcialmente. Segundo ele: "Na universidade também são elaborados ótimos trabalhos que, apesar da vontade e do empenho dos seus autores, jamais conseguem ser publicados”. Para o autor, estava posta aí “a questão dos meios de divulgação” (Goergen, 1985, p. 207-208). Na seqüência, depois de referir-se às diferentes formas de publicação, ele sintetizava a sua análise em termos nada animadores: "Além das dificuldades de publicação em forma de livro, da falta de órgãos de publicação e da carência de recursos para o uso de formas alternativas, há um outro aspecto que merece ser lembrado. As pesquisas que chegam a ser publicadas geralmente alcançam uma divulgação muito limitada” (idem, p. 208-209). E concluía propondo três medidas: "melhorar a qualidade da pesquisa, criar entre os pesquisadores a consciência da necessidade de divulgar os resultados dos seus trabalhos e aprimorar os meios de divulgação" (idem, p. 212). Infelizmente, só muito tarde, quase no esgotamento do prazo dado para este texto, me apercebi que poderia ter dedicado mais tempo e mais espaço para essas questões e propostas.

Em 1988, completadas quase duas décadas desde a arrancada da pós-graduação e decorridos dez anos desde a criação da ANPEd, em reunião de coordenadores de programas de pós-graduação em educação, realizada na manhã do dia 25 de abril de 1988, em Porto Alegre, durante a $11^{\text {a }}$ Reunião Anual, os participantes chegaram a uma avaliação preocupante em relação tanto à pós-graduação quanto à pesquisa na área. No que tange à pesquisa, o quadro então pintado colocava em evidência uma série de problemas relacionados com a produção e a publicação do conhecimento, o que mostra o quanto foi difícil o desenvolvimento da pesquisa na área:

4. Produção acadêmica. Embora venha aumentando, nos últimos anos, exige uma avaliação no que diz respeito a essa quantidade e sobretudo a sua qualidade e âmbito de divulgação. São poucos os
Programas que apresentam uma produção coletiva, fruto de projetos de pesquisa que envolvem docentes e pós-graduandos. Em alguns casos, a produção de docentes vinculados ao Programa não é contada neste. Na maioria dos casos, no entanto, é contada em dobro e até em triplo (quando o mesmo docente é vinculado a mais de um Programa). Por outro lado, grande parte das publicações são de âmbito local, ou no máximo regional. Seria necessário estabelecer critérios que traduzissem principalmente a amplitude da circulação, periodicidade, existência e funcionamento concreto de comitê editorial, nível e natureza da publicação - trabalho que começou a ser feito pelo INEP e que precisa ser retomado. (Boletim ANPEd, 1988, p. 49, grifo meu)

Em relação à pós-graduação, da qual se esperava justamente que viesse a propiciar o desenvolvimento da pesquisa, o quadro então pintado não era mais animador:

2. Problema de titulação dos docentes. Em outras áreas, sobretudo das ciências exatas e da engenharia, não há mais mestres responsáveis por disciplinas e orientação de teses. Na área de educação muitas disciplinas e também a orientação de teses muitas vezes ficam sob a responsabilidade de mestres. Há bastante dificuldade de absorção dos doutores diplomados no exterior, devido à formação específica que recebem, desvinculada das necessidades reais do curso e às vezes por não-aceitação da proposta dos Programas. [...] Há urgência na titulação de doutores, o que envolve o compromisso dos programas em liberar os mestres e a disposição destes em deslocar-se. A CAPES manifesta interesse em ajudar concretamente este esforço [...] Este ponto é fundamental também para a ANPEd, devendo ser abordado mais profundamente nesta reunião e em futuro próximo. (idem, p. 48)

A avaliação feita na referida reunião de coordenadores de pós-graduação revela algo que é preciso 
destacar, porque ajuda a entender o tamanho do desafio posto à ANPEd: ajudar a promover o desenvolvimento da pós-graduação e da pesquisa na área da educação. A mesma incipiência e a mesma precariedade de condições encontradas no campo da produção e disseminação do conhecimento repetiam-se também no ensino em nível de pós-graduação. Com efeito, decorridos cerca de dezoito anos desde a "largada" da pós-graduação, a área continuava ressentindo-se ainda da falta de doutores para formar mestres. E isso não era tudo. Lembro-me da caça a doutores, não raro com pouca produção científica, a título simplesmente de aumentar a dita "massa crítica”. E, como agravante, o desvio freqüente dos poucos doutores para funções administrativas.

Em relação a isso, surpreende positivamente a avaliação feita por Luiz Antônio Cunha por ocasião da $13^{\text {a }}$ Reunião Anual, em Belo Horizonte, em 1990. Reproduzo as palavras desse reconhecido crítico da pesquisa e da pós-graduação na área:

Foi também das dissertações e das teses dos programas de pós-graduação que saiu a quase totalidade dos livros que constituem a recente bibliografia de educação, que tem incorporado dezenas de novos títulos a cada ano. Dessa produção também saíram os artigos que abastecem as revistas da área, algumas delas mantendo muito bom nível há muitos anos. (Cunha, 1991a, p. 39)

Vejo aí uma crítica sutil à quantitativamente escassa e qualitativamente pobre produção científica de parte do corpo docente dos programas de pós-graduação na área da educação. Isso doze anos depois de o mesmo autor ter lançado, em seminário promovido pela CAPES, o desafio seguinte: “O espírito dessas colocações aponta para as pesquisas dos docentes dos programas de pós-graduação em educação como sendo sua atividade própria de pesquisa, além das teses de mestrado/doutorado" (Cunha, 1979, p. 14, grifo meu). Por mais que o autor dissesse privile-

\footnotetext{
${ }^{8}$ Ver também Cunha (1991b).
}

giar (dever ser privilegiada) a pesquisa do docente, esta só muito lentamente se foi firmando.

\section{A pesquisa e a pós-graduação na proposta de gestão 1989-1991}

Disse que o ângulo do qual projetaria meu olhar sobre a trajetória da ANPEd era o período em que fui presidente da associação por dois mandatos sucessivos: 1989-1991 e 1991-1993. É claro, falando como ator, junto com tantos outros atores: membros da diretoria, coordenadores de grupos de trabalhos, coordenadores de programas, ex-presidentes, membros de comissões, representantes junto às agências etc., e mais de mil pesquisadores associados em 1991 (Boletim ANPEd, 1991, p. 5). Por mais que tenha havido, nesse período, uma mudança de foco, relembrando fatos e revendo textos, vejo também continuidade. Quero dizer que as mudanças almejadas, em maior ou menor medida também implementadas, se orientaram para objetivos bem concretos, não contra pessoas. Diria que elas iam ao encontro de aspirações em grandíssima parte consensuais. Basta lembrar o papel desempenhado pelo então presidente Osmar Fávero na costura da chapa de $1989 .{ }^{9}$ Nesse mesmo ano, na $12^{\mathrm{a}}$ Reunião Anual, em trabalho apresentado na mesa-redonda "Papel primordial da pesquisa na pós-graduação”, Miriam Warde mostrou claramente o que estava se delineando como problema sentido e como desafio comum naquele momento. Citando Cândido Grzybowski, a pesquisadora via na dissociação reinante entre pesquisa e ensino nas universidades brasileiras a "expressão da subordinação da pesquisa ao ensino" até aquele momento (Warde, 1990, p. 68). Segundo a autora, a transferência da pesquisa de fora para dentro da universidade se dera, a partir do início dos anos de 1970, sem que a universidade

${ }^{9} \mathrm{Na}$ Assembléia Geral da 14 a Reunião Anual da ANPEd, em 1991, antes mesmo de a inscrição de chapas entrar em discussão, Osmar Fávero manifestava-se pela recondução da diretoria (Boletim ANPEd, 1991, p. 71). 
estivesse "conceitual e administrativamente preparada”, situação esta que ainda perdurava no final dos anos de 1980: “Toda a literatura analítica sobre os programas em Educação é uníssona na constatação de que carecem de condições mínimas para implementar pesquisa” (idem, p. 70). Além disso, Warde destacava o "distanciamento esquizofrênico" da pósgraduação em relação à graduação, o seu isolamento e a tendência que havia de se "chamar toda a incumbência da pesquisa à pós-graduação”, prática comum no país todo (idem, p. 70-71).

Na apresentação da proposta para o biênio 19891991, a equipe que se candidatava salientou a "dupla determinação de dar continuidade à obra construída pelas gestões anteriores e de buscar, com criatividade, resposta aos novos desafios” (Boletim ANPEd, 1989, p. 88, grifos meus). Os pontos principais da referida proposta foram organizados em quatro eixos principais: em relação à ANPEd, ${ }^{10}$ em relação aos programas, ${ }^{11}$

${ }^{10}$ Segue transcrição da Ata da Assembléia Eleitoral na parte que contém os pontos principais reunidos nos quatro eixos da proposta da chapa: "Em relação à ANPEd: reforçar o papel da ANPEd como entidade científica, autônoma e independente em relação ao Estado, condição indispensável para o desempenho de sua função de mediação das relações dos programas e pesquisadores com as agências financiadoras; ampliar a comunicação e cooperação com as associações científicas nacionais, sobretudo afins; buscar formas de intercâmbio e cooperação sistemática com outros Programas de Pós-Graduação e Pesquisa de outros países, particularmente da América Latina; garantir os meios para a articulação da Diretoria com as diversas regiões do país; continuar os esforços desenvolvidos para fazer da ANPEd um fórum permanente de discussões, respeitando as diversas abordagens metodológicas e teóricas da área educacional; redefinir as características das reuniões anuais da ANPEd, como também da dinâmica e estruturação dos Grupos de Trabalho; estudar a viabilidade da participação mais efetiva dos alunos de pós-graduação nas reuniões da ANPEd” (Boletim ANPEd, 1989, p. 88).

11 "Em relação aos Programas: oportunizar novos espaços de comunicação científica entre os Programas no sentido de cooperar na 'reciclagem' tanto dos profissionais (professores) quanto em relação às agências ${ }^{12}$ e em relação à LDB e ao Plano Nacional de Educação (PNE). ${ }^{13}$ Centralizo a discussão que segue em alguns pontos.

Antes, porém, desejo esclarecer um ponto que me parece importante. Considero que a proposta de gestão para o período 1989-1991 não foi nem apresentada nem entendida como uma proposta de ruptura; que, ao contrário, ela expressava ao mesmo tempo inovação e continuidade. Seria um equívoco fazer

dos alunos dos Programas de Pós-Graduação; discutir com os comitês assessores uma política clara de apoio, expansão e fortalecimento dos programas; desenvolver formas de apoio aos Programas em consolidação, bem como aos emergentes, especialmente no que concerne ao compromisso com a pesquisa e à publicação da produção científica; levantar e avaliar os meios de disseminação científica existentes na área, objetivando garantir a periodicidade, qualidade e circulação, condição indispensável de melhoria para os próprios Programas de pós-Graduação; oportunizar mecanismos para uma relação mais estreita entre os Programas de Pós-Graduação e a Graduação” (idem, p. 88).

12 “Em relação às agências: ampliar a política de concessão de bolsas incluindo-se apoio aos recém-graduados no mestrado e a bolsa tipo ‘sanduíche’ para doutorado no país; estudar as formas de incorporação pela ANPEd da gerência do Programa de Intercâmbio, tendo em vista a permanente e necessária atualização dos professores e alunos dos Programas de Pós-Graduação; acompanhar o desenvolvimento do Projeto de Avaliação dos Programas proposto pela ANPEd à CAPES; favorecer a permanente participação na escolha dos membros dos comitês de educação e o retorno das informações desses à comunidade científica; aumentar a sua participação efetiva, em termos de recursos financeiros, ao subsidiar eventos como os das reuniões anuais da ANPEd” (idem, p. 88-89).

13 “Em relação à Lei de Diretrizes e Bases e ao Plano Nacional de Educação: acompanhar vigilantemente e participar da elaboração do projeto da LDB e do Plano Nacional de Educação, em conformidade com os princípios firmados pela ANPEd a partir de sua reunião de 1986; manter os membros da ANPEd e da comunidade educacional em geral, informados do andamento dos trabalhos de elaboração da nova LDB e do Plano Nacional de Educação” (idem, p. 89). 
retroceder para 1989 o conflito que se manifestaria, também em São Paulo, em 1991, ao qual me referirei adiante.

\section{Estatuto científico da ANPEd: os grupos de trabalho}

Lembro que a expressão estatuto científico era muito cara à vice-presidente Marília Pontes Sposito. Numa contribuição pessoal para este artigo, ${ }^{14}$ a colega sintetizou da seguinte forma o que ela considera o primeiro ponto importante a destacar: "a introdução do comitê científico e o fortalecimento dos grupos de trabalho (GTs) como instância de discussão de trabalhos científicos, e não de troca de experiências ou de discussão de temas políticos” (Sposito, 2005). Vai no mesmo sentido esta outra avaliação: “A expansão e a consolidação dos GTs e sua forte atuação nas Reuniões Anuais mobilizaram muito a ANPEd e seus sócios em direção à produção e divulgação da produção científica” (Therrien, 2005).

O propósito de "reforçar o papel da ANPEd como entidade científica”, juntamente com a dinamização e reestruturação dos grupos de trabalho e a redefinição do formato das reuniões anuais, constituiu-se no eixo central da proposta de gestão 1989-1991 (Boletim ANPEd, 1989, p. 88). Essa questão dominou o Encontro de Avaliação e Planejamento realizado na PUC-SP, nos dias 30 de novembro e $1^{\circ}$ de dezembro de 1989 , com apoio do INEP, pouco depois da posse da nova diretoria. Entendo que esse encontro, pela representatividade dos participantes e pelo diagnóstico e encaminhamentos que dele resultaram, abriu caminho para algumas mudanças que considero fundamentais e que se impuseram daí por diante, independentemente de ênfases. Além dos membros da diretoria, participaram do encontro dois ex-presidentes; ${ }^{15}$ doze

14 Na realidade, relação de alguns tópicos importantes das gestões 1989-1991 e 1991-1993, enviada pela autora por e-mail.

${ }^{15}$ Glaura Vasquez de Miranda e Osmar Fávero. coordenadores de GTs; ${ }^{16}$ os representantes da ANPEd junto ao Programa Integrado Educação e Sociedade (PIES), ${ }^{17}$ a coordenadora do Programa de Intercâmbio e a representante do Programa de Avaliação, ${ }^{18}$ mais Maria Stephanou, assessora da presidência. A pauta contemplava seis itens: "1. Avaliação dos GTs: o que representam para a ANPEd, perspectivas de continuidade. 2. Encontros de Pesquisa: Regionais Nordeste e Sudeste. 3. Caráter (perfil) e estrutura da $13^{\mathrm{a}}$ Reunião Anual. 4. Participação da ANPEd no PIES. 5. ANPEd e Programa de Intercâmbio. 6. ANPEd e Conferência Brasileira de Educação (CBE)” (Boletim ANPEd, 1990, p. 90).

Em relação aos GTs, foi reconhecida a sua fragilidade: a grande rotatividade dos participantes, a tendência à dispersão, o fato de nem todos os GTs enfatizarem o caráter científico das sessões de trabalho, a dispersão e o caráter de imediatismo resultantes das pressões locais. Chegou-se a falar em crise e surgiram alguns encaminhamentos:

Os GTs encontram-se em crise... A ANPEd como um todo e especialmente alguns GTs viram-se profundamente envolvidos com questões conjunturais como a Constituinte, a LDB etc., chegando a sobrepor-se em certa medida a preocupação política ao caráter científico da ANPEd.

É preciso retomar a perspectiva científica, de análise, nos GTs. A Reunião Anual teria o caráter de avaliação da produção dos pesquisadores da área. Resguardar o papel ímpar da ANPEd como associação científica. [...] Os GTs devem contemplar a apresentação de trabalhos acadêmicos de fôlego, pesquisas concluídas e enviadas com antecedência por escrito. As sessões devem evidenciar o caráter científico das atividades desenvolvidas. (idem, p. 90-91, grifos no original)

${ }^{16}$ Ana Lúcia França Magalhães, Clarice Nunes, Gaudêncio Frigotto, Jacques Therrien, Niuvenius Paoli, Iracema Lima Pires Ferreira, Janete Lins Azevedo, Maria Aparecida Ciavatta Franco, Tereza Roserley Neubauer da Silva, Sérgio Haddad, Regina Alcântara de Assis e Marly André.

${ }^{17}$ Iracy Picanço e Valdemar Sguissardi.

${ }^{18}$ Bernardete Gatti e Ana Maria Saul, respectivamente. 
Segue indicação de a ANPEd articular uma série de elementos que até então haviam dado suporte aos GTs: o financiamento à pesquisa, a promoção de pesquisas consorciadas, o Programa de Intercâmbio, na prática baseado inteiramente sobre os GTs; e mais um ponto fundamental, qual seja, o de a ANPEd "desencadear um processo de avaliação dos GTs a partir de uma problematização de desafios [...] postos pela realidade" (idem, p. 90).

O processo de avaliação dos GTs sugerido nesse encontro teve seguimento, com ampla participação de seus coordenadores. Como contraponto, nas propostas e encaminhamentos tentou-se resguardar e, ao mesmo tempo, articular o denominado papel político e científico da entidade:

O papel político da ANPEd junto à LDB foi fundamental para o reconhecimento da entidade. Este papel deve ser mantido e intensificado, mas tendo presente que a ação política só será eficaz na medida em que efetivamente se preservar a aprofundar o estatuto científico da entidade. (idem, p. 91, grifos meus)

Independentemente da linguagem da época, a leitura que faço não é de oposição entre político e científico, mas sim entre duas opções políticas: uma voltada mais para o que se poderia chamar de definição das políticas de educação no Brasil; outra centrada no aprofundamento do caráter científico da associação, envolvidas aí a produção e disseminação do conhecimento e a consolidação da pósgraduação. A manifestação de Gaudêncio Frigotto, na Assembléia Geral por ocasião da $13^{\mathrm{a}}$ Reunião Anual, em Belo Horizonte, parece reforçar minha interpretação:

O professor Gaudêncio afirmou entender que a ANPEd é um espaço para se dinamizar a produção de pesquisas e teorizar sobre problemas, para que as políticas sociais tenham consistência. A ANPEd torna-se política pela consistência das alternativas que apresenta. Acrescentou que se, por um lado, a ANPEd contribui para a redefinição dos programas de pós-graduação, fazendo com que os mesmos superassem a divisão estanque das áreas de especialização, por outro, a trajetória da ANPEd não reverteu em uma fecunda autocrítica dos GTs. (idem, p. 82)

Toda a discussão sobre os GTs na ANPEd passou a ser coordenada pelo vice-presidente Miguel Arroyo e se estendeu pelas sucessivas reuniões anuais, até a $15^{\text {a }}$, realizada em 1992, em Caxambu.

Na Assembléia Geral havida na $14^{\mathrm{a}}$ Reunião Anual, em São Paulo, em 1991, foi aprovada a "Proposta da Diretoria sobre a nova concepção de reunião anual e funcionamento dos GTs” e, em 27 de novembro do mesmo ano, a presidência da ANPEd nomeou comissão constituída pelos ex-presidentes da entidade (Jacques Velloso, Maria Julieta Costa Calazans, Glaura Vasquez de Miranda e Osmar Fávero) e o vice-presidente Miguel Gonzales Arroyo para "realizar estudo para avaliar a trajetória e estrutura atual dos GTs e encaminhar proposta para a próxima Reunião Anual”, o que foi feito por meio do documento Histórico e avaliação dos grupos de trabalho (ANPEd, 1992).

O estudo produzido pela comissão contém o documento datado de 29/5/1992, com os seguintes itens: definição da função dos GTs; critérios para a criação de novos GTs; critérios para funcionamento dos GTs; seleção de trabalhos, publicações, intercâmbios e relação com o Comitê Científico; sugestões para financiamento e eleição de coordenadores, suas tarefas, relações intergrupos e com a diretoria da ANPEd. Contém também textos elaborados por dez GTs, entregues à secretaria geral até 8/9/1992.

Concluo este item com a avaliação de Henriques sobre o papel desempenhado pelos GTs nesse período. Na leitura da autora, com apoio nas informações reunidas no Boletim ANPEd (1992), a gestão daquele período poderia ser pensada como tendo priorizado "a ampliação e a qualidade das pesquisas desenvolvidas no campo da Pós-Graduação em Educação”, e, nesse sentido, uma das bases de sustentação da ANPEd teria sido o "estímulo à produção científica através da atuação dos grupos de trabalho” (Henriques, 1998, p. 134). 


\section{Estatuto científico da ANPEd: formato da reunião anual}

Outro ponto fundamental da proposta 1989-1991 dizia respeito ao formato da reunião anual. No já referido Encontro de Avaliação e Planejamento realizado no final de 1989, mereceu também especial atenção a redefinição do formato ou perfil da reunião anual. Acentuou-se que ela deveria contemplar a reflexão teórica a partir de pesquisas concluídas, e que representava um espaço para apresentação da produção dos programas, mas que isso se vinha mostrando problemático, porque estes eram "muito mais docência do que pesquisa”. Observou-se ainda que a reunião deveria ser um espaço de aprofundamento, o que poderia resultar num processo de "purificação" dos GTs (Boletim ANPEd, 1990, p. 90-91). Reproduzo, a seguir, as propostas então formuladas, pela importância que atribuo às mesmas no desenrolar dos acontecimentos nos anos seguintes:

2. Propostas.

a. Quanto à temática: o “tom” da Reunião Anual deveria ser “a pesquisa em educação” (balanço da área) - impasses teóricos, perspectivas, temas abandonados etc.;

b. Convidar, todos os anos, uma figura internacional, a fim de instigar os pesquisadores;

c. Convidar pesquisadores de outras áreas;

d. Instituir um Comitê Científico (intergrupal) para análise dos trabalhos inscritos; [...]

e. Encomendar de participantes do GT estudo/texto acerca do estado da pesquisa no tema específico do grupo. Os papers encomendados deverão circular por todos os GTs;

f. Além dos trabalhos nos GTs, prever grandes momentos (simpósios, painéis, cursos) para discussão de temas de relevância;

g. A instauração de um processo de avaliação da ANPEd sugere que a Reunião Anual se constitua num momento de reflexão por excelência. Assim, a Reunião poderia ser realizada em local retirado (hotel-fazenda) com ambiente apropriado para uma reunião de caráter científico. O objetivo seria a realização de uma Reunião mais concentrada como experiência. Seria uma ótima oportunidade para avaliação dos GTs. Isto porque não devemos confundir a Reunião Anual com extensionismo. Neste sentido, mais vale um bom trabalho, que socialize bons textos, do que socializar discursos. (idem, p. 91, grifos meus)

Deixando para logo mais a questão do comitê científico, destaco aqui três encaminhamentos que, penso, foram fundamentais. O primeiro diz respeito à ênfase posta na produção e socialização de textos. Podia-se observar, então, certa saturação no que se relacionava com participações que raramente resultavam em textos para publicação, e também em relação ao predomínio, em alguns GTs, de atividades sem muita relação com a produção do conhecimento na área.

Mas a experiência mostrou logo que não bastava a exigência de inscrição de trabalhos na íntegra, no lugar de apenas resumos. Os trabalhos inscritos para a $13^{\mathrm{a}}$ Reunião Anual diferiam muito entre si quanto a um ou mais dos seguintes critérios: quanto à extensão (número de páginas), que era extremamente variável; quanto à qualidade pelo aspecto do conteúdo e quanto à qualidade do ponto de vista da forma. Era, pois, necessário que se estabelecessem regras que permitissem uma padronização mínima, de sorte a obter trabalhos quanto possível prontos para publicação na forma de artigos ou capítulos de livros. Foi esse o caminho tentado para a reunião anual seguinte (a $14^{\mathrm{a}}$ ).

O segundo ponto refere-se à abertura para as áreas de conhecimento vizinhas, o que já se realizou na $13^{a}$ Reunião Anual, em Belo Horizonte, com a participação de Francisco de Oliveira, em sua fala de abertura do evento abordando o tema "A armadilha neoliberal e as perspectivas da educação” (idem, p. 3-14), e Cândido Grzybowski, abordando o tema "Modelo de desenvolvimento, democracia e educação" (idem, p. 15-29). A participação internacional só viria nas reuniões seguintes.

O terceiro ponto a ressaltar foi a sugestão de se buscar um "local retirado" para a reunião anual. O 
local escolhido acabou sendo Caxambu, cidade que passou a sediar quase todas as reuniões anuais a contar de 1992. Se bem me lembro, a sugestão de um local retirado e a indicação de Caxambu foi da expresidente Glaura Vasquez de Miranda. Estive pessoalmente em Caxambu, percorrendo, com o então gerente do Hotel Glória, todas as dependências do referido hotel e dos hotéis vizinhos, para avaliar as condições de hospedagem e de realização de um evento que comportava grande número de atividades simultâneas, como a Reunião Anual da ANPEd, que tem como base a sua estrutura de GTs. Foram programadas inclusive pequenas reformas, como divisão de ambientes, para tal fim.

O raciocínio, então, era que Caxambu apresentava grandes vantagens:

1) como local retirado, favoreceria o almejado caráter científico da reunião e evitaria que esta se transformasse num evento de massa;

2) favoreceria o contato e a convivência entre os participantes;

3) permitiria enorme economia de passagens aéreas, porquanto pelo menos os deslocamentos a partir de São Paulo, Rio de Janeiro, Espírito Santo e Minas Gerais poderiam ser feitos por rodovia, o que possibilitaria o financiamento para participantes provindos do Norte, Nordeste, Centro-Oeste e Sul.

Imaginava-se, para 1992, algo como 250 participantes. Na véspera do evento, percorri todos os principais hotéis, tendo contado, surpreso, cerca de 500 reservas!

Retorno a 1990. Em sua fala na Assembléia Geral, o vice-presidente Miguel G. Arroyo sintetizou a sua avaliação (e da diretoria) da $13^{\mathrm{a}}$ Reunião Anual em termos que mostram muito claramente a relação ou articulação estratégica entre GTs, reunião anual e programas de pós-graduação:

O professor Miguel acentuou que não só a preparação, mas também a gestão da reunião, procurou ser a mais participativa possível. Um ponto central é que a Diretoria procurou criar condições para que a reunião se constituísse um espaço de apresentação e discussão da produção dos programas e das áreas de pesquisa. Por isso a ênfase nas atividades dos GTs e a exigência de trabalhos escritos. Informou que foram apresentados cerca de 140 trabalhos. Isto expressa a busca de privilegiamento do caráter científico da Reunião Anual e da discussão em torno desta produção. (Boletim ANPEd, 1990, p. 80)

Na mesma assembléia, Miguel G. Arroyo surpreendeu com outra informação extremamente animadora, que se referia ao engajamento dos GTs no processo de mudança:

Retomando a palavra, o professor Miguel G. Arroyo tratou do item referente aos GTs. Informou que todos os 14 GTs funcionaram e que a Diretoria está comprometida em consolidar os GTS, buscando recursos para oportunizar encontros de intercâmbio não só na Reunião Anual, mas durante todo o ano. [...] Os coordenadores de GTs, em reunião, opinaram pela manutenção da exigência de inscrição de trabalhos escritos para a $14^{\mathrm{a}}$ Reunião e, além disso, que estes sejam fundamentalmente de produção, e não apenas de projetos. Além disso, sugeriram que os GTs devem priorizar a produção em determinadas temáticas, consideradas socialmente prioritárias e, ainda, que o GT deverá estimular o enriquecimento de abordagens. Sugeriram, ainda, que se estabeleçam critérios para seleção dos trabalhos, a nível do próprio grupo e, também, um Comitê Científico a nível da ANPEd, com representantes de todos os grupos, assegurando-se o máximo de imparcialidade. Esse Comitê deverá compatibilizar a seleção feita nos GTs. [...] Com relação à participação dos GTs na gestão da ANPEd, o Professor Miguel insistiu ser esta uma determinação da Diretoria e que isto deve se tornar uma prática, ter uma certa institucionalização (ex. reuniões com coordenadores de GTs e de programa). ${ }^{19}$ (idem, p. 80-81, grifos meus)

${ }^{19}$ É interessante como justamente neste ponto a palavra foi passada para o vice-presidente Ozir Tesser, para que apresentasse relato das quatro reuniões dos coordenadores de programas realizadas por ocasião da $13^{a}$ Reunião Anual (idem, 1990, p. 81). 


\section{Estatuto científico da ANPEd: comitê científico}

Como já disse, a idéia de instituição de um comitê científico também é do encontro realizado em São Paulo no final de 1989: "Instituir um Comitê Científico (intergrupal) para a análise dos trabalhos inscritos [...]” (idem, p. 91). Não foi possível organizá-lo para a $13^{a}$ Reunião Anual. Aliás, nem para a $14^{\mathrm{a}}$. Na realidade, além da dificuldade real de os associados e as associadas se disporem a assumir a tarefa, pesaram também a inexperiência e a falta, ainda, de critérios claros de constituição do comitê e de avaliação dos trabalhos. Avalio, hoje, que foi um ato de prudência não apressar o passo. A mudança tinha que ser construída participativamente, envolvendo ao mesmo tempo a reestruturação dos GTs, a redefinição do formato da reunião anual e o comitê científico. A precipitação poderia ter inviabilizado o projeto.

Conforme foi referido anteriormente, na $13^{\mathrm{a}}$ Reunião Anual foram os próprios coordenadores de GTs que informaram a Assembléia Geral de sua posição favorável à manutenção da exigência de inscrição de trabalho escrito, à definição de critérios para a seleção dos mesmos e à constituição de um comitê científico para atuar em articulação com os GTs na avaliação dos trabalhos (idem, p. 80-81).

A $14^{a}$ Reunião Anual, realizada em São Paulo, na Faculdade de Educação da USP, representou algum avanço. Embora a seleção tenha ficado ainda quase que totalmente por conta dos GTs, pôde-se avançar em termos de normalização dos resumos e textos, o que permitiu que, pela primeira vez, o Boletim ANPEd publicasse, junto com a programação do evento, todos os 178 resumos dos trabalhos selecionados, prática essa que se tornou rotina, mantendo-se até hoje. Houve também sensível melhora na qualidade dos textos em relação à reunião anterior.

Mas não foi tão tranqüila a realização, em seqüência, de dois eventos do porte da $14^{a}$ Reunião Anual da ANPEd e da 6 a Conferência Brasileira de Educação (CBE). A decisão de realizar numa mesma semana os dois eventos teve implicações importantes: $1^{\circ}$ ) a reunião anual teve que ser reduzida a apenas dois dias; $2^{\circ}$ ) a programação da reunião anual teve que se ater às sessões dos GTs, para apresentação de trabalhos, e à Assembléia Geral; $3^{\circ}$ ) outras atividades, como a análise da conjuntura política, ficaram para a $6{ }^{\mathrm{a}} \mathrm{CBE}$, organizada conjuntamente pela ANPEd, pelo Centro de Estudos em Educação e Sociedade (CEDES) e Associação Nacional de Educação (ANDE). Essa forma de organização da Reunião Anual, mesmo se respaldada em decisão da Assembléia Geral anterior e numa programação articulada juntamente com as coordenações de GTs, suscitou manifestações de inconformidade e protesto dentro da ANPEd, argumentando-se que a diretoria, ao limitar o evento à programação científica, isto é, às atividades dos GTs, tinha esvaziado o mesmo de qualquer conteúdo político num momento tão grave como aquele (Governo Collor). A diretoria entendeu que essas manifestações poderiam atingir o núcleo da proposta de gestão: a própria concepção de ANPEd e a proposta de formato de reunião anual, de comitê científico e de reestruturação dos GTs. Decidiu, por isso, ao término dos trabalhos do dia 2 de setembro de 1991, véspera da Assembléia Geral, retirar-se para um local isolado, para avaliar a situação e preparar a assembléia. Já na madrugada, chegou a um consenso quanto à pauta e ao teor de um documento a ser submetido à assembléia, o qual levou o nome de Proposta da diretoria da ANPEd sobre uma nova concepção de reunião anual e funcionamento dos GTs (Boletim ANPEd, 1991, p. 77-78).

A assembléia teve lugar na manhã do dia 3 de setembro, no anfiteatro da reitoria da USP. Anunciada e aceita a pauta, o secretário-geral, professor Nilton Bueno Fischer, em nome da diretoria, manifestou-se nos seguintes termos:

[Disse] Que tanto nas reuniões específicas, como a de coordenadores de GTs, quanto em situações informais, nas refeições, corredores, a diretoria ouviu colocações que se concentravam naquilo que se poderia chamar de "ausência de uma proposta política para a Reunião”. [...] que a Diretoria ouviu com toda a atenção as manifestações dos colegas nessas diversas instâncias e gostaria de destacar que a preparação e configuração da $14^{a}$ Reunião levou em consideração 
o princípio democrático da consulta, da gestão colegiada, da participação nos fóruns que dão força política à ANPEd, nas reuniões de coordenadores de programas e de GTs. [...] que a diretoria acatava e registrava que não houve explicitação, na programação, de que o fato de nós, pesquisadores, por resistência, estarmos reunidos neste fórum, é um ato de coragem política de realizar um evento científico nesta conjuntura, com este governo, apesar do desmantelamento da coisa pública, do agravamento da situação das agências de financiamento, da ausência de recursos, da greve nas universidades públicas, dos baixos salários e do descrédito de nossa função de pedagogos, pesquisadores, cientistas sociais. [...] que, nesse sentido, a preparação da Reunião teve isso como um dado [...] Afirmou que a especificidade da manifestação da ANPEd é diferente, por exemplo, da ANDES, como entidade sindical. [...] (idem, p. 68-69)

Vencidos os itens seguintes de pauta (relato das atividades do segundo ano de gestão, apreciação do parecer do Conselho Fiscal, manifestação sobre a gestão, constituição de novos GTs), o vice-presidente, professor Ozir Tesser, expôs, para exame e deliberação da assembléia, as propostas da diretoria relativas ao formato da reunião anual, e sobre o financiamento dos GTs e do Comitê Científico (Boletim ANPEd, 1991, p. 73). O debate teve momentos de tensão, conforme registrado em ata:

São feitas várias intervenções discutindo a proposta da diretoria e levantando, especialmente, aspectos relativos à preservação da autonomia dos coordenadores de GTs na definição das atividades do grupo; articulação efetiva dos GTs com os programas; preocupação com eventuais conflitos desta proposta com GTs que já se programaram para o próximo ano; necessidade de se garantir espaço para a diversidade dentro dos GTs; preocupação quanto ao papel do Comitê Científico; necessidade de evitar o autonomismo que fragmenta e de buscar uma articulação, um vínculo mais amplo dos grupos com a ANPEd como um todo. (idem, p. 73)

A ata da Assembléia Geral registra intervenções sumamente ricas, tanto de apoio à proposta quanto de questionamento de determinados pontos da mesma (idem, p. 73-74). Seria longo reproduzi-las. Finalmente, falando em nome de um grupo de pesquisadores, Gaudêncio Frigotto apresentou a seguinte proposta, que foi aprovada com apenas uma abstenção:

\section{[...] considerando que o debate não apresentou obje-} ções de fundo, mas sugestões, recomendações, preocupações, o grupo sugere que a proposta seja aprovada em bloco e que a diretoria incorpore à redação final do documento as propostas que sejam encaminhadas por escrito. A defesa que esse grupo faz é da coerência de que o documento expressa legitimamente um momento importante da ANPEd, a diretoria fez isso com uma precisão, a mais adequada possível, e seria de se estranhar se não tivesse havido esse rico debate. (idem, p. 74)

Com a aprovação desse encaminhamento, a gestão 1991-1993 poderia contar com três instrumentos importantes, respaldados e legitimados pela decisão da assembléia geral, conforme consta no Boletim ANPEd (1991, p. 72-77):

1) um novo formato da reunião anual, compreendendo: a) atividades relacionadas com a temática específica do evento, de responsabilidade da diretoria; b) atividades dos GTs, programadas e espontâneas, com preocupação também com o espaço para o pesquisador júnior; c) sessões integradas de dois ou mais GTs; d) sessões especiais sobre novas temáticas advindas de demanda espontânea;

2) uma comissão de estudo para avaliar a trajetória e estrutura atual dos GTs e encaminhar proposta para a próxima Reunião Anual, o que efetivamente foi feito, como se viu antes;

3) um comitê científico, com competência para julgar o mérito dos trabalhos e priorizá-los para fins de apoio financeiro, constituído por sete membros: um indicado pelos coordenadores de GTs; um indicado pelos coordenadores de programas, um indicado pela diretoria e quatro eleitos pelos associados. 


\section{Estatuto científico da ANPEd: relação com a SBPC}

As reuniões anuais da Sociedade Brasileira para o Progresso da Ciência (SBPC) têm sido espaços importantes para escoamento - se é que se pode dizer assim - da produção científica da área. Nas gestões 1989-1991 e 1991-1993, as relações com a SBPC estiveram a cargo da vice-presidente Marília Pontes Sposito, que se distinguiu tanto pela competência e dedicação quanto pelo questionamento no sentido de valorizar esse espaço e o papel nele desempenhado pela ANPEd. Houve um momento de tensão, em que Marília e eu nos reunimos com o presidente da SBPC, Ennio Candotti, na sede daquela entidade em São Paulo. A ANPEd não aceitava continuar desempenhando mero papel de "tarefeira" na avaliação dos trabalhos da área para as reuniões da SBPC. Queria dispor de espaço para poder propor e desenvolver também atividades que levassem o nome da ANPEd: simpósios, painéis etc. $\mathrm{O}$ trabalho da colega valeu a conquista desse espaço e, inclusive, a aceitação, pelo presidente da SBPC, do convite que the foi formulado para proferir a conferência de abertura na $15^{a}$ Reunião Anual, em Caxambu, abordando o tema "Política Nacional de Ciência e Tecnologia” (Boletim ANPEd, 1992, p. 9).

A relação da ANPEd com a SBPC e com as demais entidades científicas ampliou-se e aprofundouse com a constituição do Fórum de Entidades Científicas, coordenado pela SBPC, para fazer frente à política de terra arrasada na área de ciência de tecnologia no Governo Collor, fórum este que se manteve também no Governo Itamar Franco.

\section{Estatuto científico da ANPEd: Fórum dos Programas e Avaliação \& Perspectivas}

Corro o risco, aqui, de entrar em cheio no conteúdo de outros trabalhos solicitados pela ANPEd. Não podendo me omitir, procurarei ser muito sucinto.

Nos dias 10 a 12 de abril de 1991, foi realizada, na Universidade Estadual de Campinas (UNICAMP), a $1^{\text {a }}$ Reunião Técnica dos Coordenadores de Pós-Gra- duação em Educação, objetivando discutir a política de pós-graduação e a pesquisa na área, organizada pela ANPEd por demanda dos coordenadores e patrocinada conjuntamente pela Financiadora de Estudos e Projetos (FINEP), pela ANPEd e por universidades dos programas participantes (Cadernos ANPEd, 1991). Com base nos trabalhos apresentados e nas discussões havidas na reunião, os participantes chegaram a uma série de conclusões e recomendações, relacionadas tanto à definição da política de pós-graduação e ao papel da ANPEd nessa definição, quanto à produção científica na área. Esse evento "mexeu” bastante com os programas. A partir dele as atividades dos coordenadores por ocasião da reunião anual ampliaram-se, em termos de número de participantes e de tempo ocupado, com tendência a constituírem-se essas atividades num evento próprio, realizado imediatamente antes da reunião anual. Em sua fala nessa primeira reunião técnica de coordenadores, Carlos Roberto Jamil Cury fazia observação de extrema importância sobre o papel que os programas e a ANPEd estavam assumindo na definição da política de pós-graduação: "Podese, pois, inferir destas considerações, se procedentes, que uma política de Pós-Graduação em Educação não depende mais só do Estado, quaisquer que sejam suas iniciativas”. E justificava: “Já se conta com outros pólos, divergentes ou não de poder, que buscam a realização de interesses, finalidades e objetivos" (Cury, in: Cadernos ANPEd, 1991, p. 20). Maria Julieta C. Calazans fez três observações interessantes a respeito, que vale serem lembradas: a primeira, que foi com essa convicção que foi criado o Fórum de Programas; a segunda, que o fórum trabalhou com uma pauta provisória até a reunião da ANPEd em setembro; a terceira, que, por ocasião da $16^{\text {a }}$ Reunião Anual, nos dias 12 a 16 de setembro de 1993, o fórum "apresentou-se com uma pauta densa, tratando o tema Desafios para a Pós-Graduação em Educação no Brasil” (Calazans, 1995, p. 50-51).

Na segunda reunião técnica dos coordenadores, realizada em 1993, em Belo Horizonte, os participantes decidiram pela constituição de um fórum de programas de pós-graduação em educação como uma 
instância com programação própria dentro da ANPEd. Aqui fica uma questão a esclarecer. Na sessão de abertura da $12^{\text {a }}$ Reunião Anual, em 1989, na USP, o presidente Osmar Fávero destacara como um dos pontos fortes da gestão 1985-1989 “a constituição do Fórum dos Coordenadores de Programas de PósGraduação, que tem se reunido sistematicamente no primeiro dia dos encontros anuais" (Boletim ANPEd, 1989, p. 85). Com certeza, nem a prática de reunião dos coordenadores nem o nome "fórum de coordenadores” constituíam novidade quando da proposta da primeira reunião técnica de coordenadores, em 1990, e da realização da segunda reunião técnica, em 1993, oportunidade em que foi criado o Fórum de Coordenadores de Programas de Pós-Graduação em Educação (Boletim ANPEd, 1993b, p. 8ss).

Em 1991, a pedido do CNPq, a ANPEd assumira a realização da avaliação da área, tarefa que foi coordenada pelo colega Carlos Roberto Jamil Cury, com participação de numerosa equipe de pesquisadores da associação. O resultado foi um volume intitulado Avaliação e perspectivas na área da educação: 1982$1991^{20}$ (ANPEd, 1993), com doze textos, num total de 227 páginas, que abordam os mais variados aspectos da pós-graduação e da produção e socialização do conhecimento, os quais foram amplamente coletivizados e discutidos nas reuniões da ANPEd. O coordenador do projeto avaliou positivamente a parceria com o CNPq, desenvolvida no pior momento o de terra arrasada do Governo Collor: "Sobre este campo [do apoio financeiro], é preciso dizer que, da parte do CNPq, obtivemos a melhor resposta possível, dentro de uma política governamental de 'terra arrasada'” (Cury, 1993, p. 3) -, e destacou o papel da ANPEd, que "não poupou esforços, colocando à

${ }^{20}$ Projeto desenvolvido pela ANPEd, por solicitação e com apoio do CNPq, com a coordenação de Carlos Roberto Jamil Cury e participação dos pesquisadores: Antonio Chizzotti, Bernardete A. Gatti, João Pitombeira de Carvalho, Maria Julieta Costa Calazans, Maria Rita Neto Sales Oliveira, Maria M. Malta Campos, Miriam Jorge Warde, Osmar Fávero, Tina Amado e Walter Garcia. disposição do projeto recursos próprios no sentido de um SOS-pesquisa”, e dos autores, que "associaram os módicos recursos recebidos ao esforço pessoal em poder trazer para a área um retrato do aspecto investigado e analisado por cada um” (idem, ibidem).

Depois de amplamente expostas e discutidas na associação as diferentes contribuições da avaliação realizada, chegou à diretoria a informação de que o CNPq optara por não publicar o documento, com o argumento de que uma avaliação tão rigorosa feita pelos pares poderia "expor” a área da educação perante as demais áreas. O referido documento foi então distribuído aos pesquisadores que participaram de sua elaboração e aos programas de pós-graduação em educação. Penso que ainda é válido disponibilizar, talvez por meio digital, esse documento importante para a pós-graduação e a pesquisa na área. No entanto, não é o caso de discutir aqui se o referido argumento é fato ou versão. Basta dizer que, em setembro de 1993, na apresentação desse estudo, a diretoria ressaltou que via, na criação do Fórum Nacional de Coordenadores de Programas de Pós-Graduação em Educação e na conclusão da Avaliação e perspectivas na área de educação: 1982-1991, publicada em 1993, dois momentos importantes da trajetória da ANPEd, e que, não obstante o enorme conjunto de dificuldades enfrentadas pela universidade e pela pesquisa no Brasil naquela conjuntura, reiterava a "disposição de trabalho e de luta” (ANPEd, 1993).

\section{Estatuto científico da ANPEd: a explosão de textos}

Posiciono-me no ângulo de visão escolhido •início dos anos de 1990. De lá dirijo meu olhar na direção de 2005, tendo à mão os diferentes volumes da programação das reuniões anuais que se foram sucedendo. ${ }^{21} \mathrm{O}$ que vejo? Vou tentar esquematizar.

${ }^{21}$ Por exemplo: Boletim ANPEd 1993a, 1994, 1995; Reunião Anual da ANPEd nº 19, de 1996; 22, de 1999; 24, de 2001; e 27, de 2004. 
Em 2004 foram inscritos 697 textos, dos quais 622 foram selecionados para avaliação (495 trabalhos e 107 pôsteres), tendo sido aprovados 290 para apresentação, o que equivale a 41,6\% do total de inscritos.

Com exceção de 1997 e 1998, quando o total de textos inscritos ficou um pouco abaixo de 600, em todos os demais anos, desde 1994 até 2004, o total de textos inscritos foi superior a 600 em cada reunião.

A grande explosão em termos de inscrição de textos deu-se na gestão 1993-1995, a ponto de suscitar preocupação na diretoria de então:

A demanda por apresentação de Trabalhos e Comunicações na Reunião Anual de 1994 superou todas as expectativas. No período 1992/93, o aumento de demanda registrada, de 236 inscritos na $15^{\text {a }}$ Reunião para 381 na reunião seguinte, foi de cerca de $61 \%$, o que apontava para a possibilidade de um aumento semelhante para 1994. Entretanto, os números agora registrados foram muito superiores a essa expectativa. O aumento geral de inscrição de Trabalhos e Comunicações alcançou o índice de 92\%, totalizando 734 efetivamente inscritos. [Não incluídos aí 44 textos não submetidos à avaliação por problemas formais.] [...] Esse fato revela o vigor da Pós-Graduação e da Pesquisa na área da Educação e o reconhecimento da ANPEd como o Fórum apropriado para a discussão da produção científica na área; ele sugere também as dificuldades trazidas para a organização deste evento e aponta para a necessidade de uma ampla avaliação dos processos e mecanismos da Reunião Anual, do seu formato, de seu significado e dos próprios rumos da Associação, de forma a orientar uma reestruturação organizacional da entidade que lhe garanta a excelência na continuidade do trabalho que vem desenvolvendo desde 1978. (Boletim ANPEd, 1994, p. 5-6)

Por um lado, surpreende essa expansão, principalmente porque havia certo temor de que um maior rigor na seleção, por obra do recém-instituído comitê científico, viesse a afastar pesquisadores da inscrição de trabalho nas reuniões anuais. Por outro lado, fica a questão de saber se 600 a 700 textos inscritos e cerca de 33 a 42\% de textos selecionados para apresentação constituiriam o limite para a associação. ${ }^{22}$

Ao mesmo tempo, na medida em que se foram afirmando, os encontros regionais de pesquisa transformaram-se em verdadeiros escoadouros, junto com a reunião anual, da produção na área. ${ }^{23}$

\section{Estatuto científico da ANPEd: a tão sonhada revista}

Uma revista da ANPEd era um sonho anterior a 1989. Nas duas gestões de que participei (1989-1991

${ }^{22}$ Após a conclusão deste texto, obtive informação de que a $28^{\text {a }}$ Reunião Anual, a realizar-se em outubro do corrente ano de 2005, está superando a marca dos 900 trabalhos inscritos. Tal fato atesta indiscutivelmente a grande vitalidade da área da educação, que se expressa na capacidade de um aumento cumulativo da produção científica. Mas ele coloca também, para os organizadores, o desafio de como contemplar na programação de cada reunião anual um número crescente de trabalhos selecionados.

${ }^{23}$ Reproduzo aqui o depoimento de Jacques Therrien (2005) sobre a importância dos encontros regionais, particularmente a longa experiência do Nordeste: “Do lado regional, a realização de Encontros Regionais de Pesquisa e Pós-graduação, organizados pelos Programas de Pós-Graduação nos moldes dos encontros anuais da ANPEd, permitiu ampla divulgação da produção científica local além de possibilitar maior intercâmbio entre os docentes e pesquisadores. Esses encontros, particularmente nas regiões Norte e Nordeste, tornaram-se fatores que viabilizaram a criação de novos programas, além de facilitarem o acesso à produção científica da área. Com o apoio da SUDENE, ao qual se juntaram o CNPq e a CAPES no Seminário de Pesquisa Educacional no Nordeste, realizado em Recife em novembro de 1980, deu-se início aos encontros regionais anuais, o primeiro deles realizado em João Pessoa, em 1981. Posteriormente, esses encontros ocorreram a cada dois anos, chegando ao XVII Encontro, em Belém do Pará, em 2005. Nos mesmos moldes, incentivados nos contextos da ANPEd, as demais regiões brasileiras passaram a realizar encontros regionais, embora com menor freqüência, mas com grande participação dos professores, pesquisadores e alunos dos programas de pós-graduação”. 
e 1991-1993), pelo menos por duas vezes a diretoria se comprometeu com a sonhada criação da revista. O sonho, no entanto, só haveria de se tornar realidade no final da gestão seguinte (1993-1995, liderada pelo saudoso colega Neidson Rodrigues), com o lançamento do número zero da Revista Brasileira de Educação. No editorial desse número lê-se que a revista era a concretização de um projeto que vinha sendo preparado havia algum tempo e que resultava de um processo de amadurecimento da ANPEd em termos tanto quantitativos quanto qualitativos. Lê-se também a seguinte avaliação:

A consolidação do Comitê Científico, que, juntamente com os coordenadores dos grupos de trabalho temáticos, seleciona, de acordo com critérios sistemáticos e impessoais, os textos apresentados nas reuniões anuais, contribuiu significativamente para um salto de qualidade no trabalho desenvolvido pelos diversos grupos. [...] Este número zero inclui textos que foram apresentados na XVII Reunião Anual da ANPEd, realizada em outubro de 1994, além de artigos de pesquisadores de outros países. (Revista Brasileira de Educação, 1995, p. 3)

As reuniões anuais sempre alimentaram os periódicos da área. Mas entendo que os encaminhamentos que resultaram da assembléia geral por ocasião da $14^{a}$ Reunião Anual, em São Paulo, em 1991, relativas ao formato da reunião anual, ao perfil dos GTs e ao Comitê Científico, permitiram um avanço quantitativo, até o limite da própria reunião anual, e, principalmente, um avanço qualitativo ininterrupto na produção de conhecimento e na publicação dos textos produzidos, tanto em periódicos quanto em livros e outras formas de socialização do saber. Sposito (2005) destaca "os cadernos ${ }^{24}$ que divulgaram os bons traba-

${ }^{24}$ Sposito refere-se aos Cadernos ANPEd, números 4 e 5 (1993a, 1993b), com conferências e trabalhos da 15 Reunião Anual, realizada em Caxambu em 1992, e números 6 e 7 (1994a, 1994b), referentes à $16^{\text {a }}$ Reunião Anual, realizada em 1993, também em Caxambu. lhos, prática que depois se esgotou”, e a produção em CD-ROM das teses e dissertações, no que "fomos uma das entidades pioneiras”.

É verdade que a ANPEd não foi nem é a única entidade a produzir conhecimento na área. Muita coisa tem sido produzida em parceira com outras associações. Basta lembrar as CBEs, em suas várias edições, sempre realizada em parceria com o CEDES e a ANDE. É fácil localizar em muitos gabinetes de pesquisadores os cinco volumes dos trabalhos apresentados na $6^{\text {a }} \mathrm{CBE}$, em São Paulo, em 1991. Esse aspecto foi muito bem sintetizado por Therrien (2005):

Em nível nacional, a postura política da ANPEd junto a outras instituições, principalmente por ocasião da realização das CBEs, constituiu um marco histórico em perspectiva de definição da política nacional de educação. O Fórum Nacional da Educação, que atuou tanto por ocasião da Constituição de 1988 como nos debates que conduziram para a LDB de 1996, criou suas raízes nos encontros das CBEs, onde tanto a divulgação da produção científica como o debate de política de educação e de pós-graduação tiveram amplo espaço de manifestação.

Mas é também verdade que, contando a área, hoje, com textos de qualidade em relativa quantidade; com a garra de tantos editores e conselhos editoriais de periódicos da área; com algum apoio financeiro público e até das próprias universidades (mesmo que em estado de penúria); com o estímulo da Plataforma Lattes (mesmo que, por vezes, assumindo a forma de aguilhão!); com o imenso e árduo trabalho de avaliação e classificação dos periódicos da área, trabalho esse já ensaiado em diferentes momentos anteriores da ANPEd, ${ }^{25}$ depois ampliado e aprofundado nas últimas e na atual gestão, tudo isto torna, hoje, de algu-

${ }^{25}$ Basta lembrar o texto de Antônio Chizzotti, “Avaliação e perspectivas da pesquisa através das publicações em periódicos” (1993), que fecha o documento Avaliação e perspectivas na área da educação: 1982-1991, já referido anteriormente. Acredito que, se o autor fosse avaliar hoje os dez ou quinze anos que se 
ma forma irreconhecível a área da educação para os sonhadores de quinze anos atrás.

Penso que, com os encaminhamentos de então, ganhou a reunião anual, ganharam os GTs, ganharam os programas de pós-graduação, ganhou a ANPEd, ganhou a área de conhecimento. Ganharam também as reuniões regionais. Por exemplo, a ANPEd Sul de 2004, realizada em Curitiba, apresentou-se com ares de reunião anual: com mais de mil participantes, com um grosso volume contendo a programação e os resumos, e um CD-ROM divulgando na íntegra todos os textos selecionados para o evento.

Aliás, a introdução do meio digital para publicação na íntegra dos trabalhos aceitos para apresentação nas reuniões anuais e regionais representou um avanço enorme no que se refere à disseminação da produção científica dos pesquisadores e dos programas de pós-graduação. Se bem me lembro, isso aconteceu pela primeira vez no final da década de 1990, na segunda gestão presidida por Maria Malta Campos, prática esta adotada também nas reuniões anuais seguintes e logo introduzida nos $3^{\circ}, 4^{\circ}$ e $5^{\circ}$ Seminário de Pesquisa em Educação da Região Sul (2000, 2002 e 2004). Faltam-me informações sobre sua adoção nas demais reuniões regionais.

\section{Conclusão}

Estendi-me excessivamente, e assim mesmo devo ter omitido muita coisa.

Peço escusas por ambas as falhas. Concluo externando a convicção e o sentimento de que, mesmo na discordância sobre alguns pontos, por vezes até importantes, as sucessivas gestões da ANPEd souberam discernir, preservar e inclusive aperfeiçoar,

seguiram ao período por ele examinado, reformularia bastante o teor de seu julgamento. "Uma análise genérica do conteúdo dessas publicações [dizia ele em 1993] mostra que são poucos os periódicos que incluem, entre seus objetivos editoriais, a publicação de pesquisas e, mesmo quando declaram incluí-las em suas secções de edição, é, na maioria, modesta e quase inexistente a publicação delas, ao menos nos últimos seis anos” (p. 217). na caminhada, iniciativas e realizações que se foram firmando como conquistas coletivas e permanentes. Se a diretoria do período 1993-1995, que teve à frente o saudoso colega, amigo e sucessor na presidência da ANPEd, Neidson Rodrigues, falou em se garantir a excelência na continuidade do trabalho que vinha sendo desenvolvido desde 1978 (in: Boletim ANPEd, 1994, p. 5-6), eu desejaria encerrar este texto almejando a mesma excelência na continuidade do trabalho que nos aguarda nos anos que estão por vir.

ALCEU RAVANELLO FERRARO, doutor em ciências sociais pela Pontifícia Universidade Gregoriana (Roma, Itália), em 1969, professor titular aposentado da Universidade Federal do Rio Grande do Sul (UFRGS), é atualmente professor titular da Escola Superior de Teologia, em São Leopoldo (RS), e pesquisador do Conselho Nacional de Desenvolvimento Científico e Tecnológico (CNPq). Publicou: Igreja e desenvolvimento: o Movimento de Natal (Natal: Fundação José Augusto, 1968); Diagnóstico da escolarização no Brasil (Revista Brasileira de Educação, São Paulo: ANPEd, nº 12, set.-dez., 1999, p. 22-47); Analfabetismo e níveis de letramento no Brasil (Educação e Sociedade, Campinas: CEDES, v. 23, nº 81, dez. 2002, p. 2147); Escolarização no Brasil na ótica da exclusão (In: MARCHESI, Á., HERNADEZ GIL, C. Fracasso escolar: uma perspectiva multicultural, Porto Alegre: ARTMED, 2004, p. 48-65); Analfabetismo no Brasil: desconceitos e políticas de exclusão (Perspectiva, Florianópolis, UFSC, v. 22, n 1, jan.-jun., 2005, p. 111-125); com RIBEIRO, M., publicou Movimentos sociais: revolução e reação (Pelotas: EDUCAT, 1999) e organizou Trabalho Educação Lazer: construindo políticas públicas (Pelotas: EDUCAT, 2001). Atualmente desenvolve, com apoio do CNPq, o projeto de pesquisa "Escola brasileira: quem são os excluídos? Alfabetização, escolarização e letramento em relação a classe social, gênero e cor/raça, a partir dos censos demográficos”. E-mail: aferraro@adufrgs.ufrgs.br

\section{Referências bibliográficas}

ANPEd, (1992). Histórico e avaliação dos grupos de trabalho. Caxambu (MG): ANPEd, 60p. (1993). Avaliação e perspectivas na área da educação: 1982-1991. Porto Alegre: ANPEd, Diretoria, 227p. 
, (1995). Apresentação. In: CALAZANS, Maria Julieta

Costa. ANPEd: trajetória da pós-graduação e pesquisa em educação no Brasil. Belo Horizonte: ANPEd, Diretoria, p. 5-6.

BOLETIM ANPEd, (1986). Niterói (RJ): ANPEd, v. 8, nº 3-4, jul./dez., 92p.

, (1995). Apresentação. Belo Horizonte (MG), 17ª Reunião Anual, p. 5-9.

, (1988). Niterói (RJ): ANPEd, v. 10, nº 2-3, abr.-set., 88p. , (1989). Niterói (RJ): ANPEd, no 1-2, jan.-jun., 108p. , (1990). Porto Alegre (RS): ANPEd, no 1-2, jan.dez., 92p.

, (1991). Porto Alegre (RS): ANPEd, n 1-2, jan.dez., 184p.

, (1992). Porto Alegre (RS): ANPEd, $\mathrm{n}^{\circ}$ 1, set., 149p. , (1993a). Porto Alegre (RS): ANPEd, $n^{\circ} 1$, set., 147p. , (1993b). Belo Horizonte (MG): ANPEd, nº 2, out.dez., 128p.

(1994). Belo Horizonte (MG): ANPEd, no 1, out., 302p.

(1995). Belo Horizonte (MG): ANPEd, nº 1, set., 257p.

BRANDÃO, Zaia, (1986). A pesquisa em educação e o impacto do crescimento da pós-graduação no Brasil. Em Aberto, Brasília, ano 5, no 31 , p. 25-30.

CADERNOS ANPEd, (1991). Política de pós-graduação e pesquisa em educação. Organização: Nilton Bueno Fischer. Porto Alegre: ANPEd, no 3, 53p.

, (1993a). Conferências. Porto Alegre: ANPEd, $n^{\circ} 4$, 77p. In: REUNIÃO ANUAL DA ANPEd, 15., 1991, Caxambu (MG), Anais..., Porto Alegre: Anped, n 4, 77p.

, (1993b). In: REUNIÃO ANUAL DA ANPEd, 15. 1992, Caxambu - Trabalhos. Porto Alegre: ANPEd, nº 5, 274p. , (1994a). In: REUNIÃO ANUAL DA ANPEd, 16., 1993, Caxambu - Conferência e Sessões Especiais. Belo Horizonte: ANPEd, $n^{\circ}$ 6, 274p.

, (1994b). In: REUNIÃO ANUAL DA ANPEd, 16. 1993, Caxambu - Trabalhos. Belo Horizonte: ANPEd, n. 7, 172p.

CALAZANS, Maria Julieta Costa, (1995). ANPEd: trajetória da pós-graduação e pesquisa em educação no Brasil. Belo Horizonte: ANPEd, 137p.

CHIZZOTTI, Antônio, (1993). Avaliação \& perspectivas da pesquisa através das publicações em periódicos. In: ANPEd. Ava- liação e perspectivas na área da educação: 1982-1991. Porto Alegre: ANPEd, p. 217-227.

CUNHA, Luiz Antônio, (1979). Os (des)caminhos da pesquisa na pós-graduação em educação. In: SEMINÁRIO SOBRE A PRODUÇÃO CIENTÍFICA NOS PROGRAMAS DE PÓS-GRADUAÇÃO EM EDUCAÇÃO, Curitiba, 1978. Brasília: Departamento de Documentação e Divulgação/CAPES, p. 3-28. , (1991a). Pós-graduação em educação: no ponto de inflexão? Cadernos ANPEd, n ${ }^{\circ} 3$ - Política de pós-graduação e pesquisa em educação, Porto Alegre: ANPEd, p. 39-48.

, (1991b). Pós-graduação em educação: no ponto de inflexão. Cadernos de Pesquisa, São Paulo, n 77, p. 63-67.

CURY, Carlos Roberto Jamil, (1991). Política de pós-graduação e pesquisa em educação. Cadernos ANPEd, n ${ }^{0} 3$ - Política de pós-graduação e pesquisa em educação, Porto Alegre: ANPEd, p. $7-24$.

, (1993). Avaliação e perspectivas na área de educação: 1982-1991. Documento síntese. In: ANPEd. Avaliação e perspectivas na área da educação: 1982-1991. Porto Alegre: ANPEd, p. 1-29.

FÁVERO, Osmar, (1993). Política de pós-graduação em educação no Brasil. Niterói: Universidade Federal Fluminense. Tese de concurso para professor titular na área de Política da Educação, 89p.

GATTI, Bernardete, (1983). Pós-graduação e pesquisa em educação no Brasil: 1978-1981. Cadernos de Pesquisa, São Paulo, $\mathrm{n}^{\circ} 44$, p. 3-17.

GOERGEN, Pedro, (1985). A divulgação da pesquisa educacional. Revista Brasileira de Estudos Pedagógicos, Brasília, v. 66, nº 153, p. 201-214.

, (1986). A pesquisa educacional no Brasil: dificuldades, avanços e perspectivas. Em Aberto, Brasília, ano 5, ${ }^{\circ}$ 31, p. 1-18.

GOUVEIA, A. J., (1971). A pesquisa educacional no Brasil. Cadernos de Pesquisa, São Paulo, Fundação Carlos Chagas, $n^{\circ} 1$, p. $1-48$.

HENRIQUES, Vera Maria Pereira de Miranda, (1998). ANPEd e a preocupação da autonomia: em busca de reconhecimento e consagração. Tese de doutorado. Pontifícia Universidade Católica do Rio de Janeiro, 191p.

LOURENÇO FILHO, (1940). Estatística e educação. Revista Brasileira de Estatística, Rio de Janeiro, ano 1, $\mathrm{n}^{0}$ 1, jan.-mar., p. 66-85. 
A ANPEd, a pós-graduação, a pesquisa e a veiculação da produção intelectual na área da educação

MARTINS, Ricardo C. de Rezende, (1991). A pós-graduação no Brasil: uma análise do período 1970-90. Educação Brasileira, Brasília, v. 13, n 27, p. 93-119.

REUNIÃO ANUAL DA ANPEd, 19., (1996), Caxambu (MG). Programa e resumos. Caxambu (MG): ANPEd, 1996, 283p. REUNIÃO ANUAL DA ANPEd, 22., (1999), Caxambu (MG). Programa e resumos. Caxambu (MG): ANPEd, 1999, 358p. REUNIÃO ANUAL DA ANPEd, 24., (2001), Caxambu (MG).

Programa e resumos. Caxambu (MG): ANPEd, 2001, 231p. REUNIÃO ANUAL DA ANPEd, 27., (2004), Caxambu (MG).

Programa e resumos. Caxambu (MG): ANPEd, 2004, 423p. REVISTA BRASILEIRA DE EDUCAÇÃO, (1995). Editorial. Belo

Horizonte: ANPEd, $n^{\circ}$ 0, p. 3-4. SEMINÁRIO SOBRE A PRODUÇÃO CIENTÍFICA NOS PROGRAMAS DE PÓS-GRADUAÇÃO EM EDUCAÇÃO, (1979),
Curitiba, 1978. Brasília: Departamento de Comunicação e Divulgação/CAPES, 1979, 147p.

SPOSITO, Marilia Pontes. Depoimento sobre a ANPEd. S.l.: s.ed. THERRIEN, Jacques, (2005). Memória viva da ANPEd: um depoimento. S.l.: s.ed.

VIEIRA, Sofia Lerche, (1985). A pesquisa em educação no Brasil. Cadernos de Pesquisa, São Paulo, Fundação Carlos Chagas, $\mathrm{n}^{\circ} 55$, p. 81-84.

WARDE, Miriam, (1990). O papel da pesquisa na pós-graduação em educação. Cadernos de Pesquisa, São Paulo, Fundação Carlos Chagas, $n^{\circ} 73$, p. 67-75.

Recebido em abril de 2005 Aprovado em junho de 2005 


\section{Resumos/Abstracts}

Alceu Ravanello Ferraro

\begin{abstract}
AANPEd, a pós-graduação, a pesquisa e a veiculação da produção intelectual na área da educação

Posicionando-se nos anos de 1989 a 1993, quando, por dois biênios sucessivos, integrou, como presidente, a diretoria da ANPEd, o autor inicia dirigindo o olhar para as condições da emergência da pós-graduação em educação (início dos anos de 1970) e da criação da
\end{abstract} ANPEd (1978), focalizando também a natureza da associação e os desafios por ela enfrentados em seus primeiros onze anos de atuação. Analisa então a política de privilegiamento do estatuto científico da associação, que compreendeu uma série de iniciativas relacionadas com os grupos de trabalho, o formato das reuniões anuais, o Comitê Científico, a relação com a Sociedade Brasileira para o Progresso da Ciência (SBPC), a criação do Fórum dos Programas de Pós-Graduação em Educação e a pesquisa Avaliação e perspectivas na área de educação: 1982-1991. Por fim, dirigindo o olhar para os anos que se seguiram, destaca iniciativas como a criação da Revista Brasileira de Educação, a dinamização dos encontros regionais de pesquisa e o grande avanço, quantitativo e qualitativo, no que se refere à produção e divulgação do conhecimento na área. Conclui externando a convicção de que, mesmo na discordância em pontos até importantes, as sucessivas gestões da ANPEd souberam discernir, preservar e inclusive aperfeiçoar, na caminhada, iniciativas que se foram firmando como conquistas coletivas e permanentes.

Palavras-chave: ANPEd; educação; pós-graduação; pesquisa; divulgação do conhecimento

AANPEd, postgraduate studies, research and the dissemination of intellectual production in the field of education

Taking the period from 1989 to 1993 when the author was president of the executive committee of the National Association of Postgraduate Studies and Research in Education - ANPEd, this article begins by examining the conditions in which postgraduate studies in education emerged (the beginning of 70's) and the creation of the National Association (1978), as well as focusing on the nature of the association and the challenges faced by it during its first eleven years of existence. It then analyses the policy of prioritising the scientific statute of the association which covered a series of initiatives related to the working groups, the format of the annualm meetings, the Scientific Committee, the relationship with the Brazilian Society for the Progress of Science, the creation of the Forum of Postgraduate Programmes in Education and the research Evaluation and Perspectives for the Field of Education: 1982-1991. Finally, focusing attention on the following years, it emphasises initiatives like the creation of the Brazilian Review of Education, the new dynamics of the regional research meetings and the great advance, both quantitative and qualitative, with relation to the production and dissemination of knowledge in the field. The article concludes externalising the conviction that, despite disagreeing on important points, the successive directorates of ANPEd knew how to discern, preserve and improve initiatives, which were to become permanent collective conquests. Key-words: ANPEd; education; postgraduate studies; research; dissemination of knowledge 